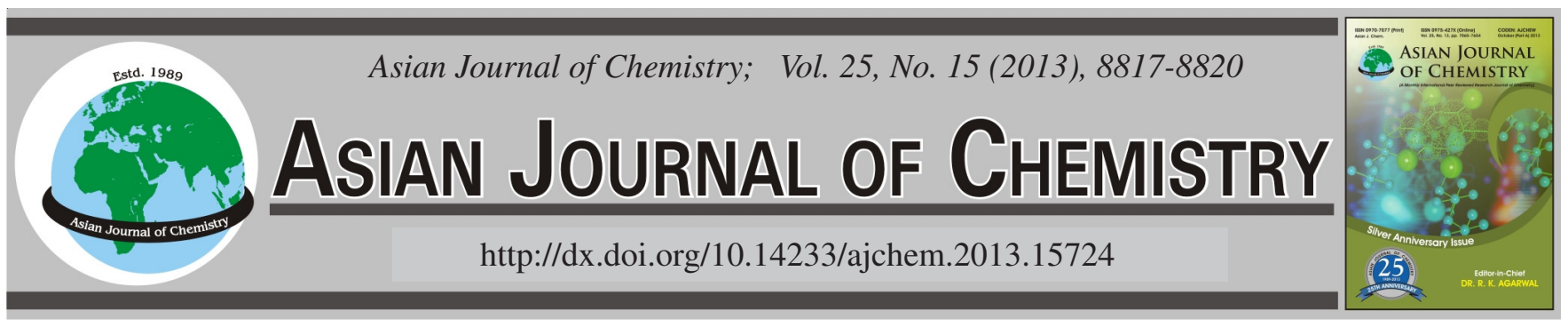

\title{
Treatability Studies on Organized Industrial District Wastewater with Chemical Treatment, Fenton and Fenton-Like Processes
}

\author{
Melike Yalili KiliC \\ Department of Environmental Engineering, Faculty of Engineering and Architecture, Uludag University, 16059 Gorukle-Bursa, Turkey
}

Corresponding author: Fax: +90 224 4428243; Tel: +90 224 2942117; E-mail: myalili@uludag.edu.tr

Organized industrial districts are established to carry out the industrialization by minimizing the environmental problems. For this reason, wastewater arises from different industries are treated by various treatment processes. In this study, the wastewater of organized industrial district which is situated in Bursa city of Demirtas district, Turkey is treated by chemical treatment with various coagulants and Fenton and Fenton-like processes. $\mathrm{Al}_{2}\left(\mathrm{SO}_{4}\right)_{3} \cdot 18 \mathrm{H}_{2} \mathrm{O}, \mathrm{FeSO}_{4} \cdot 7 \mathrm{H}_{2} \mathrm{O}$ and $\mathrm{FeCl}_{3} \cdot 6 \mathrm{H}_{2} \mathrm{O}$ were used in chemical treatment studies and 72,78 and $78 \%$ COD removal, 59, 41 and $50 \%$ suspended solid removal were obtained, respectively. Fenton and Fenton-like processes showed high COD $(>60 \%)$ and suspended solid $(>75 \%)$ removal performance on evaluated effluents.

Key Words: Chemical treatment, Fenton and Fenton like oxidation, Organized industrial district wastewater.

\section{INTRODUCTION}

Organized industrial districts (OIDs) are models which have been used by State Planning Organization (SPO) in Turkey, to provide balanced development and regular urbanization, to build industries that do not cause environmental problems ${ }^{1}$.

Today in Turkey, 261 organized industrial districts have been become a legal entity. While the completed organized industrial district projects were only 70 until the year of 2002 . In the last 10 years, 77 organized industrial district projects were completed and the total number of organized industrial district projects increased to 147 . The works on infrastructure and treatment plant lending of 65 organized industrial districts have been continued in the investment program of 2012. Also, it is planned to have been completed of 15 organized industrial districts projects by the end of $2012^{2}$.

Rapid growth of organized industrial districts has increased the usage of water ${ }^{3}$. The discharged wastewater amount was 190 million $\mathrm{m}^{3}$ in 2010, according to the results obtained from the 134 organized industrial districts directorate, via Water, Wastewater and Waste Statistics Survey of 2010. The total treated wastewater amount was 161 million $\mathrm{m}^{3}$ and advanced, biological, physical or chemical treatment were applied on $58.5,40.1$ and $1.4 \%$ of treated wastewater, respectively ${ }^{4}$.

The applications of conventional treatment processes are not sufficient to obtain the discharge criteria of wastewater. Therefore, advanced treatment processes have been applied and thus, reclamation and reuse of wastewater is provided.
Because reclaimed water is an alternative water supply for countries which suffer from water scarcity ${ }^{5}$.

The main objective of this study is to investigate of treatability of organized industrial district wastewater by chemical treatment, Fenton and Fenton-like processes. For this purpose, various coagulants such as $\mathrm{Al}_{2}\left(\mathrm{SO}_{4}\right)_{3} \cdot 18 \mathrm{H}_{2} \mathrm{O}, \mathrm{FeSO}_{4} \cdot 7 \mathrm{H}_{2} \mathrm{O}$ and $\mathrm{FeCl}_{3} \cdot 6 \mathrm{H}_{2} \mathrm{O}$ were used in chemical treatment. The results of treatment studies are presented as a function of chemical oxygen demand (COD) and suspended solids (SS).

\section{EXPERIMENTAL}

Characteristics of Demirtas Organized Industrial District wastewater: Demirtas organized industrial district (DOID) is situated in Bursa, northwest of Turkey and provides employment opportunities for 37,529 people. It contains 414 factories from different industrial sectors such as textile, automotive and sub-industry, machine, electrical and electronic tools, furniture and forest products, metal, food, chemistry, packing, petroleum products and other industries (Table-1). The domestic and industrial wastewaters of the DOID are discharged to Nilufer river by open and closed canals ${ }^{6}$. Demirtas Organized Industrial District (DOID) wastewater treatment plant that meets the discharge criteria enforced by the Turkish Water Pollution Control Legislation ${ }^{7}$ having a flow rate 70,000 $\mathrm{m}^{3} /$ day and the DOID wastewater is treated by physical and biological treatment.

Raw wastewater samples used in this study were collected from the homogenization tanks of DOID and analyzed in 


\begin{tabular}{lc}
\hline \multicolumn{2}{c}{ TABLE-1 } \\
\multicolumn{1}{c}{ Category } & Number of firms \\
\hline \multicolumn{1}{c}{ INDUSTAL CLASSIFICATION IN DOID } \\
\hline Textile & 267 \\
Automotive and sub-industry & 49 \\
Machine & 10 \\
Electrical and electronic tools & 3 \\
Furniture and forest products & 6 \\
Metal & 12 \\
Food & 15 \\
Chemistry & 30 \\
Packing & 3 \\
Petroleum products & 2 \\
Other industries & 17 \\
Total & 414 \\
\hline
\end{tabular}

accordance with Standard Methods ${ }^{8}$. Environmental characterization of DOID wastewater is given in Table-2. The experiments were carried out on the samples in order to remove COD and suspended solid.

\begin{tabular}{ccc}
\multicolumn{3}{c}{ TABLE-2 } \\
CHARACTERIZATION OF WASTEWATER \\
\hline Parameter & Unit & Value \\
\hline $\mathrm{pH}$ & - & 8.96 \\
$\mathrm{COD}$ & $\mathrm{mg} / \mathrm{L}$ & 1008 \\
Suspended solid & $\mathrm{mg} / \mathrm{L}$ & 460 \\
$\mathrm{EC}$ & $\mathrm{mS} / \mathrm{cm}$ & 4.82 \\
\hline
\end{tabular}

Chemical treatability studies: Chemical treatability experiments were performed at room temperature $\left(20 \pm 1{ }^{\circ} \mathrm{C}\right)$ with $1 \mathrm{~L}$ samples in a Jar Test apparatus (Velp Scientifica, Model FC6S, Italy). The $\mathrm{pH}$ of the samples was adjusted with the addition of $\mathrm{H}_{2} \mathrm{SO}_{4}$ and $\mathrm{NaOH}$. Samples were left for precipitation for $1 \mathrm{~h}$ after $2 \mathrm{~min}$ of rapid mixing (120 rpm) and 15 min of slow mixing $(20 \mathrm{rpm})$. Then, analytical analyses were carried out on chemically treated wastewater.

Fenton and Fenton-like experiments: Fenton and Fenton-like experiments were conducted at room temperature $\left(20 \pm 1^{\circ} \mathrm{C}\right.$ ) using varying $\mathrm{FeSO}_{4} \cdot 7 \mathrm{H}_{2} \mathrm{O}-\mathrm{H}_{2} \mathrm{O}_{2}$ (for Fenton experiments) and $\mathrm{FeCl}_{3} \cdot 6 \mathrm{H}_{2} \mathrm{O}-\mathrm{H}_{2} \mathrm{O}_{2}$ (for Fenton-like experiments) dosages at varying $\mathrm{pH}$ values in order to determine optimum dosages give better results in COD and suspended solid removal. The $\mathrm{pH}$ was manually adjusted to desired range $(\mathrm{pH}$ 2-6) using $1 \mathrm{~N}$ sulphuric acid and/or sodium hydroxide before starting the experiments. During the determination of optimum $\mathrm{pH}$ value, doses of $\mathrm{FeCl}_{3} \cdot 6 \mathrm{H}_{2} \mathrm{O}, \mathrm{FeSO}_{4} \cdot 7 \mathrm{H}_{2} \mathrm{O}$ (supplied from Merck) and $\mathrm{H}_{2} \mathrm{O}_{2}$ (supplied from Merck, $35 \%$, w/w) were fixed at $200 \mathrm{mg} / \mathrm{L} . \mathrm{H}_{2} \mathrm{O}_{2}, \mathrm{FeSO}_{4} \cdot 7 \mathrm{H}_{2} \mathrm{O}$ and $\mathrm{FeCl}_{3} \cdot 6 \mathrm{H}_{2} \mathrm{O}$ dosages, change between 100 and $350 \mathrm{mg} / \mathrm{L}$ were used to decide chemical dosages after the optimum $\mathrm{pH}$ was determined. Sedimentation over $2 \mathrm{~h}$ was applied following the $\mathrm{pH}$ adjustment (7.5-8.0) after 2 min of rapid mixing at $120 \mathrm{rpm}$ and $20 \mathrm{~min}$ of slow mixing were applied at Jar Test setup. COD and suspended solid analyses were performed on wastewater supernatant, which was taken after $2 \mathrm{~h}$ precipitation.

Analytical procedure: To decompose residual $\mathrm{H}_{2} \mathrm{O}_{2}$, which interferes with the COD, the samples containing $\mathrm{H}_{2} \mathrm{O}_{2}$ were treated with $\mathrm{MnO}_{2}$ powder ${ }^{9,10}$. The concentration of residual $\mathrm{H}_{2} \mathrm{O}_{2}$ in the test solution was measured using test strips (Merck Merckoquant Peroxide Test). Before each analysis, the samples were filtered on $0.45 \mu \mathrm{m}$ Millipore membranes to remove $\mathrm{MnO}_{2}$. The $\mathrm{pH}$ and conductivity values were measured with a $\mathrm{pH}$ meter (Sartorius, Model PB-11, Germany) and a WTW 315I conductivity meter (WTW, Germany), respectively. COD (closed reflux method) and suspended solid were measured in accordance with Standard Methods ${ }^{8}$.

\section{RESULTS AND DISCUSSION}

Chemical treatment studies: The effect of $\mathrm{pH}$ with various coagulants $\left(\mathrm{Al}_{2}\left(\mathrm{SO}_{4}\right)_{3} \cdot 18 \mathrm{H}_{2} \mathrm{O}, \mathrm{FeSO}_{4} \cdot 7 \mathrm{H}_{2} \mathrm{O}\right.$ and $\mathrm{FeCl}_{3} \cdot 6 \mathrm{H}_{2} \mathrm{O}$ ) on COD removal was shown in Fig. 1. In chemical treatment studies, the COD removal increased until the $\mathrm{pH} 7$ and 9 whereas the removal of COD decreased beyond the $\mathrm{pH}$ 7 and 9, when $\mathrm{Al}_{2}\left(\mathrm{SO}_{4}\right)_{3} \cdot 18 \mathrm{H}_{2} \mathrm{O}$ and $\mathrm{FeSO}_{4} \cdot 7 \mathrm{H}_{2} \mathrm{O}$ were used, respectively. When $\mathrm{FeCl}_{3} \cdot 6 \mathrm{H}_{2} \mathrm{O}$ was used, the maximum COD removal was obtained at $\mathrm{pH} 4$. The optimum $\mathrm{pH}$ values for the chemical treatment with $\mathrm{Al}_{2}\left(\mathrm{SO}_{4}\right)_{3} \cdot 18 \mathrm{H}_{2} \mathrm{O}, \mathrm{FeSO}_{4} \cdot 7 \mathrm{H}_{2} \mathrm{O}$ and $\mathrm{FeCl}_{3} \cdot 6 \mathrm{H}_{2} \mathrm{O}$ were determined as 7, 9 and 4, respectively.

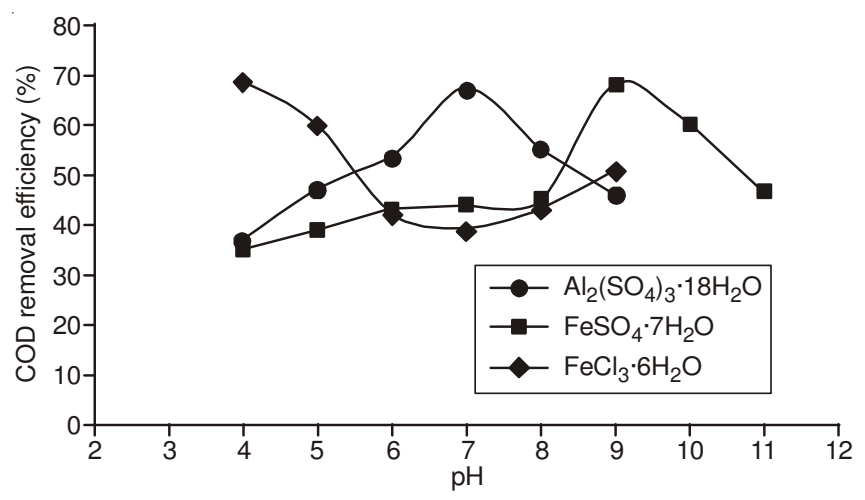

Fig. 1. Effect of $\mathrm{pH}$ on COD removal during chemical treatment studies

Fig. 2 shows the effects of $\mathrm{Al}_{2}\left(\mathrm{SO}_{4}\right)_{3} \cdot 18 \mathrm{H}_{2} \mathrm{O}, \mathrm{FeSO}_{4} \cdot 7 \mathrm{H}_{2} \mathrm{O}$ and $\mathrm{FeCl}_{3} \cdot 6 \mathrm{H}_{2} \mathrm{O}$ doses on $\mathrm{COD}$ removal. The optimum dose of $\mathrm{Al}_{2}\left(\mathrm{SO}_{4}\right)_{3} \cdot 18 \mathrm{H}_{2} \mathrm{O}$ and $\mathrm{FeSO}_{4} \cdot 7 \mathrm{H}_{2} \mathrm{O}$ were determined as 300 $\mathrm{mg} / \mathrm{L}$ whereas the optimum dose of $\mathrm{FeCl}_{3} \cdot 6 \mathrm{H}_{2} \mathrm{O}$ was $350 \mathrm{mg} / \mathrm{L}$. The dose of $300 \mathrm{mg} / \mathrm{L}$ of $\mathrm{Al}_{2}\left(\mathrm{SO}_{4}\right)_{3} \cdot 18 \mathrm{H}_{2} \mathrm{O}$ (at pH 7) and 300 $\mathrm{mg} / \mathrm{L} \mathrm{FeSO}_{4} \cdot 7 \mathrm{H}_{2} \mathrm{O}$ (at $\mathrm{pH} 9$ ) resulted in $49 \%$ of suspended solid and $37 \%$ of suspended solid removal efficiency, while $\mathrm{FeCl}_{3} \cdot 6 \mathrm{H}_{2} \mathrm{O}$ removed $40 \%$ suspended solid at a dose of 350 $\mathrm{mg} / \mathrm{L}$ (at pH 4) (Fig. 3).

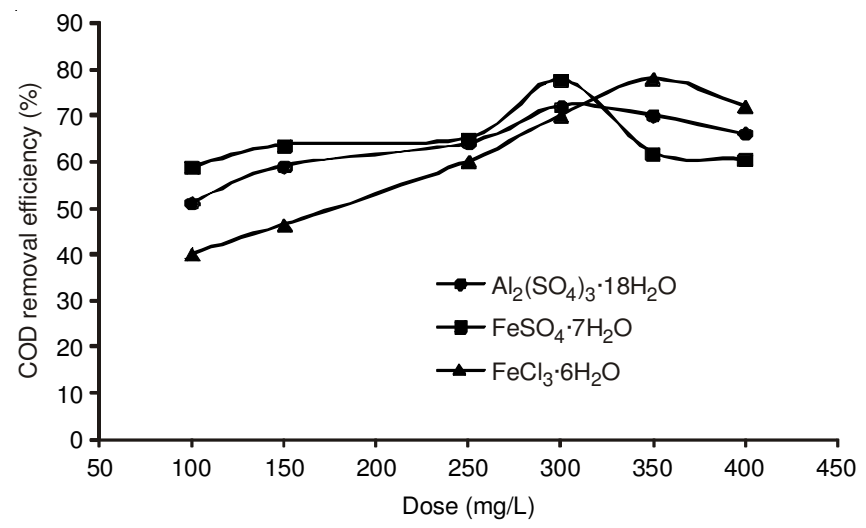

Fig. 2. Effects of coagulants dose on COD removal during chemical treatment studies 


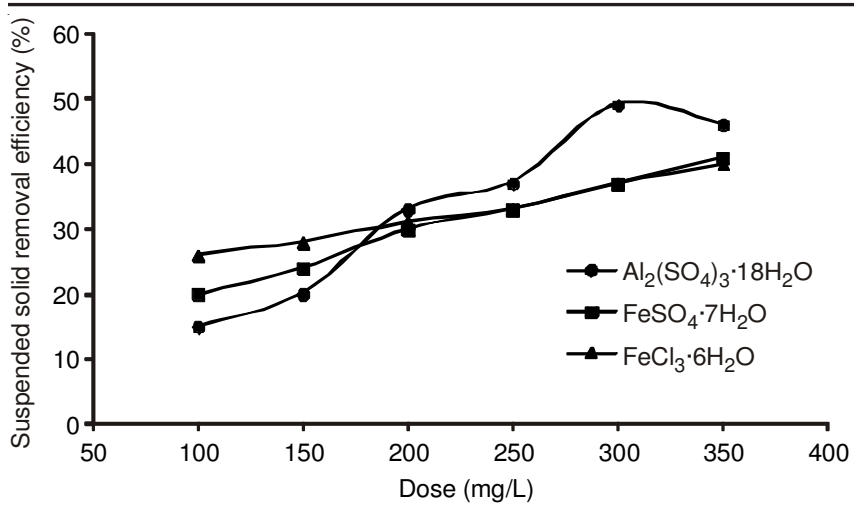

Fig. 3. Effect of coagulants dose on suspended solid removal during chemical treatment studies

Eker and Çiner ${ }^{11}$ applied the chemical treatment with various coagulants, such as $\mathrm{Al}_{2}\left(\mathrm{SO}_{4}\right)_{3} \cdot 18 \mathrm{H}_{2} \mathrm{O}, \mathrm{FeCl}_{3} \cdot 6 \mathrm{H}_{2} \mathrm{O}$ and $\mathrm{FeSO}_{4} \cdot 7 \mathrm{H}_{2} \mathrm{O}$ to the wastewater of Sivas Organized Industrial District. They obtained $84 \% \mathrm{COD}$ and $55 \%$ suspended solid removal at a dose of $400 \mathrm{mg} / \mathrm{L} \mathrm{Al}_{2}\left(\mathrm{SO}_{4}\right)_{3} \cdot 18 \mathrm{H}_{2} \mathrm{O}$ at $\mathrm{pH}$. When they used $\mathrm{FeCl}_{3} \cdot 6 \mathrm{H}_{2} \mathrm{O}$ and $\mathrm{FeSO}_{4} \cdot 7 \mathrm{H}_{2} \mathrm{O}$ at a dose of $250 \mathrm{mg} / \mathrm{L}$ at $\mathrm{pH} 8,76$ and $73 \% \mathrm{COD}, 52 \%$ suspended solid and $37 \%$ suspended solid removal were obtained, respectively. In another study done by Çiner and Eker ${ }^{12}, \mathrm{Al}_{2}\left(\mathrm{SO}_{4}\right)_{3} \cdot 18 \mathrm{H}_{2} \mathrm{O}$, $\mathrm{FeCl}_{3} \cdot 6 \mathrm{H}_{2} \mathrm{O}$ and $\mathrm{FeSO}_{4} \cdot 7 \mathrm{H}_{2} \mathrm{O}$ were used in chemical treatment studies of Sivas organized industrial district and all these coagulants proved high COD removal $(>70 \%)$, but relatively low TSS solid removal (around $50 \%$ ). Üstün et al. ${ }^{13}$ removed 45-50 \% COD and 84-96\% suspended solid with $\mathrm{Al}_{2}\left(\mathrm{SO}_{4}\right)_{3} \cdot 18 \mathrm{H}_{2} \mathrm{O}, \mathrm{FeCl}_{3}$ and $\mathrm{Fe}_{2}\left(\mathrm{SO}_{4}\right)_{3}$ by adding anionic polyelectrolyte in chemical treatment studies.

Fenton and Fenton-like processes: The operating $\mathrm{pH}$ and the dosages of $\mathrm{FeSO}_{4}$ and $\mathrm{FeCl}_{3}$ are the parameters that affect the Fenton and Fenton-like processes. The optimum $\mathrm{pH}$ has been observed to be 3 in Fenton processes ${ }^{14-16}$. Also, the oxidation potential of hydroxyl radicals $\left({ }^{\circ} \mathrm{OH}\right)$ is known to decrease with an increase in the $\mathrm{pH}^{17}$.

In this study, the optimum $\mathrm{pH}$ value for the Fenton and Fenton-like processes was determined by adjusting the $\mathrm{pH}$ from 2-6. The resulting COD removal efficiencies were observed. As shown in Fig. 4, the maximum COD removal efficiency occurred at $\mathrm{pH} 3$ for these two processes. The COD removal efficiencies for DOID wastewater at $\mathrm{pH} 3(200 \mathrm{mg} / \mathrm{L}$ $\mathrm{FeSO}_{4} \cdot 7 \mathrm{H}_{2} \mathrm{O}, 200 \mathrm{mg} / \mathrm{L} \mathrm{FeCl} \cdot 6 \mathrm{H}_{2} \mathrm{O}$ and $200 \mathrm{mg} / \mathrm{L} \mathrm{H}_{2} \mathrm{O}_{2}$ dosages) were $58 \%$ for the Fenton process and $60 \%$ for the Fenton-like processes, respectively.

Other important operational parameters of Fenton and Fenton-like processes are $\mathrm{H}_{2} \mathrm{O}_{2}, \mathrm{FeSO}_{4} \cdot 7 \mathrm{H}_{2} \mathrm{O}$ and $\mathrm{FeCl}_{3} \cdot 6 \mathrm{H}_{2} \mathrm{O}$ concentrations. In these two processes, a constant $\mathrm{H}_{2} \mathrm{O}_{2}$ concentration of $250 \mathrm{mg} / \mathrm{L}$ at $\mathrm{pH} 3$ and dosages of $\mathrm{FeSO}_{4} \cdot 7 \mathrm{H}_{2} \mathrm{O}$ and $\mathrm{FeCl}_{3} \cdot 6 \mathrm{H}_{2} \mathrm{O}$ between 100 and $350 \mathrm{mg} / \mathrm{L}$ were used to determine the optimum concentrations. Fig. 5 shows the COD removal efficiencies at a constant $\mathrm{H}_{2} \mathrm{O}_{2}$ concentration and the varied $\mathrm{FeSO}_{4} \cdot 7 \mathrm{H}_{2} \mathrm{O}$ and $\mathrm{FeCl}_{3} \cdot 6 \mathrm{H}_{2} \mathrm{O}$ dosages. The optimum $\mathrm{FeSO}_{4} \cdot 7 \mathrm{H}_{2} \mathrm{O}$ and $\mathrm{FeCl}_{3} \cdot 6 \mathrm{H}_{2} \mathrm{O}$ dosages were determined as $250 \mathrm{mg} / \mathrm{L}$ for both Fenton and Fenton-like processes.

The other significant parameter in the Fenton and Fentonlike processes is the $\mathrm{H}_{2} \mathrm{O}_{2}$ dosage. The $\mathrm{H}_{2} \mathrm{O}_{2}$ dosage influences the degradation process and excess $\mathrm{H}_{2} \mathrm{O}_{2}$ interferes with COD

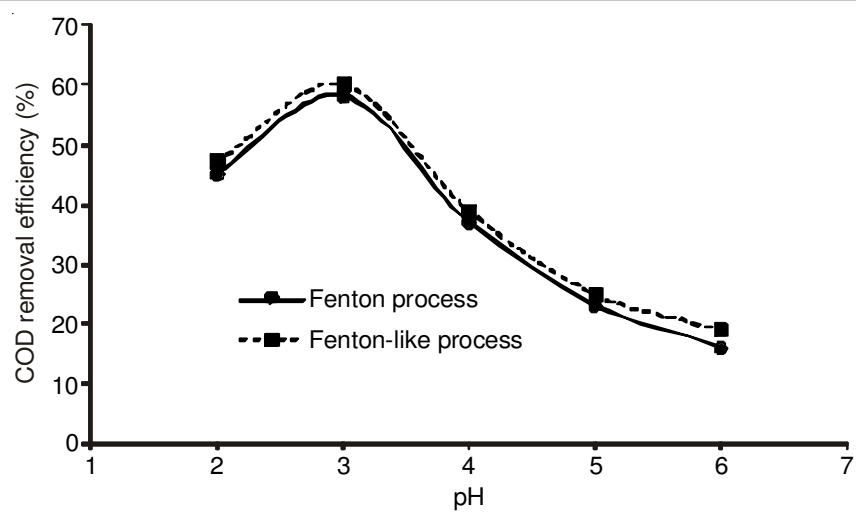

Fig. 4. Effect of $\mathrm{pH}$ on $\mathrm{COD}$ removal during Fenton and Fenton-like processes $\left(\mathrm{C}_{\mathrm{FeSO}_{4}}=200 \mathrm{mg} / \mathrm{L}, \mathrm{C}_{\mathrm{FeCl}_{3}}=200 \mathrm{mg} / \mathrm{L}\right.$ and $\mathrm{C}_{\mathrm{H}_{2} \mathrm{O}_{2}}=200$ $\mathrm{mg} / \mathrm{L}$ )

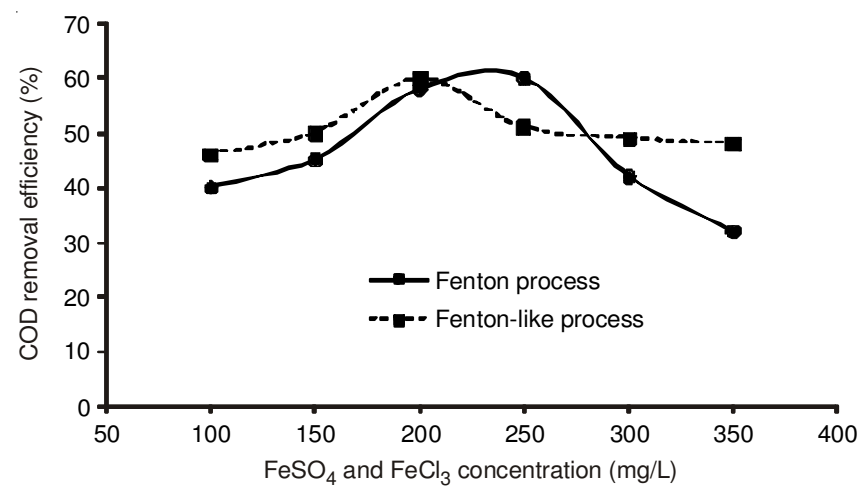

Fig. 5. Effect of $\mathrm{FeSO}_{4} \cdot 7 \mathrm{H}_{2} \mathrm{O}$ and $\mathrm{FeCl}_{3} \cdot 6 \mathrm{H}_{2} \mathrm{O}$ concentrations on COD removal efficiencies during Fenton and Fenton-like processes $(\mathrm{pH}$ $=3$ and $\mathrm{CH}_{2} \mathrm{O}_{2}=250 \mathrm{mg} / \mathrm{L}$ )

measurements. The residual $\mathrm{H}_{2} \mathrm{O}_{2}$ in the Fenton process can consume $\mathrm{K}_{2} \mathrm{Cr}_{2} \mathrm{O}_{7}$, which leads to an increase in the inorganic $\mathrm{COD}^{18}$. Studies aimed at determining the optimum $\mathrm{H}_{2} \mathrm{O}_{2}$ dosage were conducted at the previously determined $\mathrm{FeSO}_{4} \cdot 7 \mathrm{H}_{2} \mathrm{O}$ and $\mathrm{FeCl}_{3} \cdot 6 \mathrm{H}_{2} \mathrm{O}$ dosages and $\mathrm{pH}$ values. Fig. 6 shows the COD removal efficiencies at different $\mathrm{H}_{2} \mathrm{O}_{2}$ dosages (between 100 and $350 \mathrm{mg} / \mathrm{L}$ ) and constant $\mathrm{FeSO}_{4} \cdot 7 \mathrm{H}_{2} \mathrm{O}$ and $\mathrm{FeCl}_{3} \cdot 6 \mathrm{H}_{2} \mathrm{O}$ concentrations. According to the Fig. 7, the optimum $\mathrm{pH}$ value and the $\mathrm{H}_{2} \mathrm{O}_{2}$ and iron salt dosages for the Fenton and the Fenton-like processes were determined as follows: $\mathrm{pH}=3$, $\mathrm{C}_{\mathrm{H}_{2} \mathrm{O}_{2}}=250 \mathrm{mg} / \mathrm{L}$ and $\mathrm{C}_{\mathrm{FeSO}_{4}}=250 \mathrm{mg} / \mathrm{L}$ (61\% COD removal)

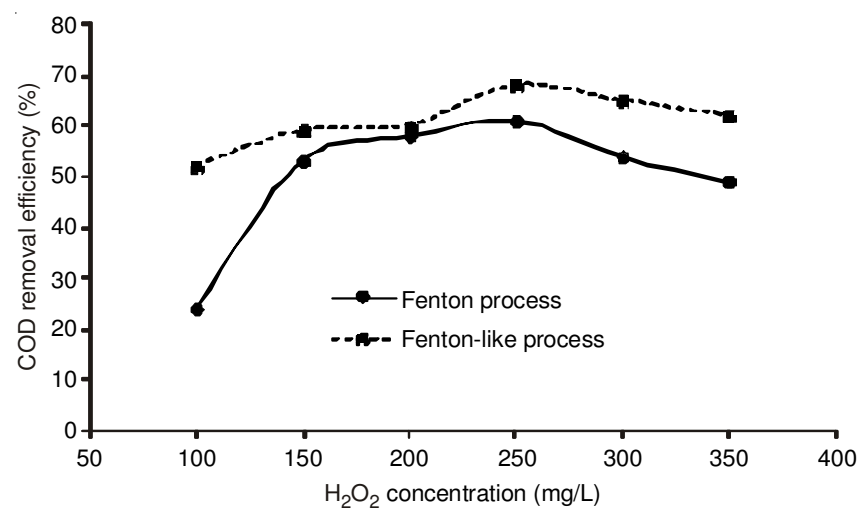

Fig. 6. Effect of $\mathrm{H}_{2} \mathrm{O}_{2}$ concentration on $\mathrm{COD}$ removal efficiencies during Fenton and Fenton-like processes (Fenton process ( $\mathrm{pH}=3$ and $\mathrm{C}_{\mathrm{FeSO}_{4}}$ $=250 \mathrm{mg} / \mathrm{L})(61 \%$ COD removal, $72 \%$ suspended solid removal $)$, Fenton-like process $\left(\mathrm{pH}=3\right.$ and $\left.\mathrm{C}_{\mathrm{FeCl}_{3}}=200 \mathrm{mg} / \mathrm{L}\right)(68 \% \mathrm{COD}$ removal, $76 \%$ suspended solid removal)) 
TABLE-3

PROCESS RESULTS FOR DOID WASTEWATER TREATMENT

\begin{tabular}{lccccccc}
\hline \multicolumn{1}{c}{ Process } & $\mathrm{pH}$ & $\begin{array}{c}\mathrm{COD} \text { removal } \\
(\%)\end{array}$ & $\begin{array}{c}\mathrm{SS} \mathrm{removal} \\
(\%)\end{array}$ & $\begin{array}{c}\mathrm{C}_{\mathrm{Al}_{2}\left(\mathrm{SO}_{4}\right)_{3} \cdot 18 \mathrm{H}_{2} \mathrm{O}} \\
(\mathrm{mg} / \mathrm{L})\end{array}$ & $\begin{array}{c}\mathrm{C}_{\mathrm{H}_{2} \mathrm{O}_{2}} \\
(\mathrm{mg} / \mathrm{L})\end{array}$ & $\begin{array}{c}\mathrm{C}_{\mathrm{FeSO}_{4} \cdot 7 \mathrm{H}_{2} \mathrm{O}} \\
(\mathrm{mg} / \mathrm{L})\end{array}$ & $\begin{array}{c}\mathrm{C}_{\mathrm{FeCl}} \cdot 6 \mathrm{H}_{2} \mathrm{O} \\
(\mathrm{mg} / \mathrm{L})\end{array}$ \\
\hline Chemical treatment with $\mathrm{Al}_{2}\left(\mathrm{SO}_{4}\right)_{3} \cdot 18 \mathrm{H}_{2} \mathrm{O}$ & 7 & 72 & 49 & 300 & - & - & - \\
Chemical treatment with $\mathrm{FeSO}_{4} \cdot 7 \mathrm{H}_{2} \mathrm{O}$ & 9 & 78 & 37 & - & - & 300 & - \\
Chemical treatment with $\mathrm{FeCl}_{3} \cdot 6 \mathrm{H}_{2} \mathrm{O}$ & 4 & 78 & 40 & - & - & - & 350 \\
Fenton process & 3 & 61 & 72 & - & 250 & 250 & - \\
Fenton-like process & 3 & 68 & 74 & - & 250 & - & 200 \\
\hline
\end{tabular}

and $\mathrm{pH}=3, \mathrm{C}_{\mathrm{H}_{2} \mathrm{O}_{2}}=250 \mathrm{mg} / \mathrm{L}$ and $\mathrm{C}_{\mathrm{FeCl}_{3}}=200 \mathrm{mg} / \mathrm{L}(68 \%$ COD removal), respectively. The COD removal efficiencies obtained from Fenton-like process were higher than those obtained from Fenton oxidation process. Also, 72 and $74 \%$ suspended solid were removed under these optimum circumstances in Fenton and Fenton-like processes, respectively.

The results of processes applied on DOID wastewater are summarized in Table- 3 and consequently, the Fenton-like process generally resulted in higher COD and suspended solid removal efficiencies.

\section{Conclusions}

In this study, chemical treatment, Fenton and Fenton-like processes were applied on organized industrial district wastewater. The following conclusions can be drawn from this study.

1. The COD removal efficiencies were similar when $\mathrm{FeSO}_{4} \cdot 7 \mathrm{H}_{2} \mathrm{O}$ and $\mathrm{FeCl}_{3} \cdot 6 \mathrm{H}_{2} \mathrm{O}$ used in chemical treatment.

2 . The most appropriate coagulant for chemical treatment is $\mathrm{FeSO}_{4} \cdot 7 \mathrm{H}_{2} \mathrm{O}$. Because, the price of $\mathrm{FeSO}_{4} \cdot 7 \mathrm{H}_{2} \mathrm{O}$ is less than $\mathrm{Al}_{2}\left(\mathrm{SO}_{4}\right)_{3} \cdot 18 \mathrm{H}_{2} \mathrm{O}$ or $\mathrm{FeCl}_{3} \cdot 6 \mathrm{H}_{2} \mathrm{O}$.

3. Fenton and Fenton-like processes have shown satisfactory COD and suspended solid removal performances on organized industrial district wastewater.

4. The COD and suspended solid removal efficiencies obtained from Fenton-like process are higher than Fenton process.

\section{REFERENCES}

1. I. Toröz, S. Meriç, I. Talinli and H.Z. Sarikaya, ITU 4, Industrial Pollution Profile Symposium, Istanbul, Turkey, p. 29 (1994).

2. $\quad$ N. Ergun, Key Develop. Produc., 24) 4 (2012).

3. S.K. Aka-Solmaz, G.E. Üstün, A. Birgül and Y. Tasdemir, Desalination, 217, 301 (2007).

4. Anonymous, www.tuik.gov.tr (2013).

5. R. Mujeriego and T. Asano, Water Sci. Technol., 40, 1 (1999).

6. Anonymous, www.bursa.gov.tr (2013)

7. Anonymous, Water Pollution Control Legislation (WPCL): 25687 issued Official Gazette, Ankara (2004).

8. APHA, AWWA, WEF, Standard Methods for the Examination of Water and Wastewater, American Public Health Association, Washington DC, USA, edn. 20 (1998)

9. M.Y. Kilic, T. Yonar and K. Kestioglu, Environ. Technol., 34, 1521 (2013).

10. B.K. Mert, T. Yonar, M.Y. Kilic and K. Kestioglu, J. Hazard. Mater. 174, 122 (2010).

11. A. Eker and F. Çiner, DEU J. Eng. Sci., 6, 97 (2004).

12. F. Çiner and A. Eker, Desalination, 211, 102 (2007).

13. G.E. Üstün, S.K. Akal Solmaz and K. Kestioglu, Uludag Univ. J. Fac. Eng. Arch., 9, 65 (2004).

14. W.Z. Tang and C.P. Huang, Environ. Technnol., 17, 1371 (1996).

15. E. Neyens and J. Baeyens, J. Hazard. Mater, B98, 33 (2003).

16. M. Vilve, A. Hirvonen and M. Sillanpää, J. Hazard. Mater, 164, 1468 (2009).

17. B.G. Kwon, D.S. Lee, N. Kang and J. Yoon, Water Res., 33, 2110 (1999).

18. I. Talinli and G.K. Anderson, Water Res., 26, 107 (1992). 